The Egyptian Journal of Hospital Medicine (January 2019) Vol. 74 (3), Page 648-659

\title{
Effect of Selective Serotonin Reuptake Inhibitors and Serotonin Norepinephrine Reuptake Inhibitors on Trabecular Bone Score and Bone Mineral Density in Primary Fibromyalgia
}

Hesham S. Hamoud, Mohamed M. Ghait, Yasser A. Hussein, Muhammad M. Harb

Department of Physical Medicine, Rheumatology and Rehabilitation, Faculty of Medicine, Al-Azhar University, Cairo, Egypt

Corresponding author: Muhammad M. Harb; Mobile: 01009952990; Email: Dr_2MH@Yahoo.com

\begin{abstract}
Background: fibromyalgia is characterized by chronic widespread pain classified as primary and concomitant. Aim of the Work: this work aimed to determine the correlation between selective serotonin reuptake inhibitors (SSRIs) and serotonin norepinephrine reuptake inhibitors (SNRIs) usage and bone mineral density (BMD) and trabecular bone score (TBS) changes in primary fibromyalgia patients.

Patients and Methods: The present study was conducted on study on 100 Egyptian patients diagnosed as primary fibromyalgia categorized according to drug medication into two 2 groups, 50 patients on SSRIs and 50 patients on SNRIs, recruited from Rheumatology, Physical Medicine and Rehabilitation Departments at Al-Hussein and Sayed Galal, Al-Azhar University Hospitals. In addition to another 50 age matched the control group subdivided into 25 primary fibromyalgia patients not on those drugs and 25 healthy individuals selected by nurses and medical staff, after an informed consent from all subjects from June 2018 to December 2018. Results: DXA and TBS revealed that usage of SSRIs and SNRI was significantly associated with low BMD (Osteopenia and osteoporosis) specially spine BMD reduction with low TBS (partially degraded and degraded) particularly for old people. Conclusion: the present study provided evidence that usage of SSRIs or SNRI was significantly associated with low BMD (Osteopenia and osteoporosis) specially spine BMD reduction with low TBS (Partially degraded and degraded) particularly for old people and despite low BMD was found in the SRI users; it also found in $1^{\text {ry }}$ fibromyalgia not on SRIs so $1^{\text {ry }}$ fibromyalgia should also be considered as a contributing factor for low BMD.
\end{abstract}

Keywords: SSRI, SNRI, FMS, fibromyalgia, osteoporosis, TBS, BMD, bone mineral density, trabecular bone score.

\section{INTRODUCTION}

Fibromyalgia is characterized by chronic widespread musculoskeletal pain that often co-exists with sleep disturbances, fatigue, cognitive dysfunction, stiffness and tenderness to palpation at specific tender points. It has been classified as primary and concomitant. Primary fibromyalgia indicates that there is no underlying or concomitant medical condition that might have contributed to a patient's pain. Fibromyalgia is considered concomitant if another condition such as osteoarthritis, rheumatoid arthritis, systemic lupus erythematosus, or hypothyroidism is present and in turn contributes to a patient's pain or fatigue ${ }^{[1]}$. Fibromyalgia is associated with low level of physical activity and exercise, which may lead to an increased risk of osteoporosis resulting in a substantial impact on quality of life ${ }^{[2]}$. Selective serotonin reuptake inhibitors represent a class of commonly used antidepressants. They act by preventing the

Received: 10/10/2018

Accepted: 29/10/2018 reuptake of 5-hydroxytryptamine (5-HT) (Serotonin) through the inhibition of the 5-HT transporter (5-HTT) which is located on the presynaptic neuron, thereby increasing levels of 5-HT within the synaptic cleft and modulating neurochemical signaling [3]. Usage of SSRIs was significantly associated with lumbar spine BMD reduction, particularly for old people ${ }^{[4]}$. Two SNRI's have gained FDA approval for the management of fibromyalgia Duloxetine and Milnacipran ${ }^{[5]}$, CaMoS study found an elevated danger of fractures in individuals who used SSRI or SNRI, even after controlling other multiple risk factors for osteoporosis ${ }^{[6]}$. Currently, DXA (Dual-energy Xray absorptiometry) scan was used to assess BMD and FRAX assessment tool to predict 10-year probability of hip fracture, the diagnosis of osteoporosis rests on a real bone mineral density (BMD) measurement using DXA. Microarchitecture of cancellous bone was a determinant for bone strength which can't be measured 
via DXA ${ }^{[7]}$. Trabecular bone score (TBS) is a texture parameter related to bone microarchitecture providing skeletal information that is not captured from the standard BMD measurement. It measures the variations in gray-level texture from 1 pixel to the next across 2 dimensional images, Trabecular bone score (TBS) seems to be an amazing surrogate noninvasive method for assessing microarchitecture texture of vertebral bone than DXA scans in routine scientific practice which will fulfill the definition of osteoporosis [8] .Recent data showed a significant added and independent predictive value of lumbar trabecular bone score (TBS) over bone mineral density (BMD) alone in the estimation of fracture risk in both women and men ${ }^{[9]}$.

\section{AIM of the WORK}

This work aim to determine the correlation between selective serotonin reuptake inhibitors (SSRIs) and serotonin norepinephrine reuptake inhibitors (SNRIs) usage and bone mineral density (BMD) and trabecular bone score (TBS) changes in primary Fibromyalgia patients.

\section{PATIENTS and METHODS}

The present cross sectional study was conducted on a Hundred (100) Egyptian patients diagnosed as primary fibromyalgia divided according to drug medication into two 2 groups, 50 patients on SSRIs and 50patients on SNRIs, recruited from Rheumatology, Physical Medicine and Rehabilitation departments at AlHussein and Sayed Galal, Al-Azhar University Hospitals. In addition to another 50 age matched the control group subdivided into 25 primary fibromyalgia patients not on those drugs and 25 healthy individuals selected by nurses and medical staff, after an informed consent from all subjects from June 2018 to December 2018..An approval was obtained from the medical ethics committee of Al-Azhar University before starting this study. All the patients were informed about the study procedures and a written consent was obtained from all of them. The subjects were categorized into three groups. Group A: $501^{\text {ry }}$ fibromyalgia patients on SSRI. Group B: $501^{\text {ry }}$ fibromyalgia patients on SNRI. Group C: 50 individuals as a the control group subdivided into: group C-1: $25,1^{\text {ry }}$ fibromyalgia patients non SRIs-users and group C-2: 25) healthy individuals.

\section{Patient's selection}

\section{A) Inclusion criteria for group A and B:}

All fibromyalgia patients had to fulfill 2010 ACR diagnostic criteria of fibromyalgia and On SSRI or SNRIs for at least 6 months

\section{B) Exclusion criteria:}

Age of participants was $<30$ years or $>65$ years rheumatoid arthritis and collagen diseases (SLE, SS, MCTD, etc.), systemic diseases e.g. hypothyroidism, TB, hepatic, renal, etc., patients on glucocorticoids for more than 6 months, chronic obstructive pulmonary disease including asthmatics IBD, autoimmune hepatitis and celiac diseases, history of traumatic vertebral fractures hospitalization due to alcohol or drug addiction pregnant or lactating women.

\section{I-Full medical history taking:}

Personal history about, name, age, sex, residence, occupation, marital status, special habits of medical importance, in addition to menstrual history and obstetric history including number of labors and abortions for female patients.

History of present illness: onset, course and disease duration. To assess risk factors and prognostic factors for osteoporosis, including age, menopausal age, anthropometric variables, physical activity (hours per week spent on jogging, gymnastics,cycling,swimming and standing/walking on the job), previous and present illnesses, gynecological history, and use of drugs, vitamin supplements, alcohol and tobacco, constitutional symptoms as fatigue, fever and loss of weight, musculoskeletal manifestations as morning stiffness, joint pain, swelling, redness, hotness and muscle pain or weakness, mucocutaneous manifestations as rash, photosensitivity, alopecia, oral ulcers, Raynaud's phenomena, skin ulcers and splinter hemorrhage, gastrointestinal manifestations as anorexia, epigastric pain, nausea, vomiting, diarrhea and constipation. renal manifestations as loin pain, hematuria, dysuria, urgency, frequency, polyuria or oliguria, puffiness of the eye lids and swelling of the lower limbs. Somatic symptoms : muscle pain, irritable bowel syndrome, fatigue/tiredness, thinking or remembering problem, muscle weakness, headache, pain/cramps in the abdomen, numbness/tingling, dizziness, insomnia, 
depression, constipation, pain in the upper abdomen, nausea, nervousness, chest pain, blurred vision, fever, diarrhea, dry mouth, itching, wheezing, Raynaud's phenomenon, hives/welts, ringing in ears, vomiting, heartburn, oral ulcers, loss of/change in taste, seizures, dry eyes, shortness of breath, loss of appetite, rash, sun sensitivity, hearing difficulties, easy bruising, hair loss, frequent urination, painful urination, and bladder spasms.

Past history: past history of chronic diseases, medications, surgery, allergy, blood transfusion or hospital admission, rheumatologic diseases, DM or other metabolic diseases, cardiac, kidney or liver diseases.

Family history: family history of RA cases or other autoimmune diseases.
II- Examination: general examination, examination of scalp, eye and skin, cardiac examination, chest examination, abdominal examination, neuropsychiatric examination and articular examination. All joints were examined as follow: inspection: overlying skin color, muscle wasting, deformity and swelling. Palpation: temperature, tenderness and swelling (soft tissue or effusion). Movement: both active and passive movement was done, with observation of pain, crepitus and protecting muscle spasm with local examination, inspection for skin changes such as discoloration, scar or rashes, swelling either generalized or localized.

Palpation: warmth, swelling either generalized or localized, synovial hypertrophy, bony enlargement, crepitus, clicking of the joint with motion.

\section{III- Assessment of tender points according to the ACR 1990 criteria:}

Table 1: fibromyalgia tender points according to the ACR 1990 criteria

\begin{tabular}{|l|l|l|l|l|l|}
\hline Right & Yes & No & Site & Yes & No \\
\hline Site & & & Low cervical region & & \\
\hline Low cervical region & & & 2nd Rib & & \\
\hline $2^{\text {nd }}$ Rib & & & Occiput & & \\
\hline Occiput & & & Trapezius & & \\
\hline Trapezius & & & Supraspinatus & & \\
\hline Supraspinatus & & & Lateral epicondyle & & \\
\hline Lateral epicondyle & & & Gluteal & & \\
\hline Gluteal & & & Greater trochanter & & \\
\hline Greater trochanter & & & Knee & & \\
\hline Knee & & 18 & & \\
\hline Total & & & \\
\hline
\end{tabular}

Score interpretation: the patient must feel pain in 11 of 18 tender point sites on digital palpation (Performed with a force of $4 \mathrm{~kg} / \mathrm{cm} 2$ ) and had a history of widespread pain (present for at least 3 months) to be considered.

IV-Assessment according to ACR 2010 diagnostic criteria of fibromyalgia:

A patient satisfies diagnostic criteria for fibromyalgia if the following 3 conditions are met:

Widespread pain index (WPI) $\geq 7$ and symptom severity (SS) scale score $\geq 5$ or WPI $\geq 3-6$ and SS scale score $\geq 9$.

$\checkmark$ Symptoms have been present at a similar level for at least 3months.

$\checkmark$ The patient does not have a disorder that would otherwise explain the pain.

\section{Investigations:}

C.B.C. analyzed using Sysmex Kx-21 N automated cell counter. 
E.S.R (assay by Westergren method) \& C.R.P (assay by BioMed-CRP latex agglutination method).Erythrocyte sedimentation rate (ESR): by Westergren method. The reading of first hour was taken.

Liver function tests: ALT, AST and Bilirubin, analyzed using Hitachi Cobas C 311 automated analyzer.

Kidney function tests: urea and creatinine, analyzed by using Hitachi Cobas C 311 automated analyzer.

Blood sugar: fasting blood glucose and 2hours post prandial blood glucose level by Hitachi Cobas C 311 automated analyzer.

Autoimmune profile: including RF, ANA, were detected by an enzyme-linked immune-sorbent assay (ELISA).

\section{E. Bone Quantity Assessment The procedure:}

Assessment of bone mineral density measured by dual-energy X-ray absorptiometry at lumbar spine, left proximal femur and left distal forearm.

Type of apparatus:

GE Medical System (GE-Lunar Prodigy Primo), Madison, WI, USA , Brand: GELunar, Model: Prodigy Primo, SN: 35156

Bone Mineral Density (BMD) or bone mass was one of the predictors of fracture. With the availability of high precision bone densitometers, the World Health Organization has established criteria for diagnosing osteoporosis.

The diagnostic score (T-score) was related to bone mass in young healthy women. Bone mineral density (BMD) above -1 SD (standard deviation) is normal, BMD between -1 and $-2.5 \mathrm{SD}$ is assigned to osteopenia, while below $-2.5 \mathrm{SD}$ is the diagnostic criterion for osteoporosis (T-score) BMD is preferably measured by dual energy $\mathrm{X}$-ray absorptiometry (DXA).

The World Health Organization has defined the following categories based on bone density:

Normal bone

T-score greater than
Osteopenia

T-score between -1

and -2.5

Osteoporosis

2.5

Severe Osteoporosis T-score less than 2.5 and history of fracture

\section{Procedure:}

\section{A- For measuring spine BMD:}

- The patient lies supine on the scan table. The scan arm and detector move to the approximate start position and the program turns on the laser light.

- Put the patient's leg on the support block until the patient's thighs are at 60-90 angle. The support block helps to separate vertebrae and straightens the lower back.

- Put the laser light approximately $5 \mathrm{~cm}$ below the patient's navel and in the same longitudinal plane as the patient's midline.

- The program automatically labels L1 to L4.

\section{B- For measuring femur BMD:}

- The patient lies flat on the scan table. The scan arm and detector move to the approximate start position and the program turns on the laser light.

- Position the laser light midway between the anterior superior iliac spine and the pubic tubercle.

- The program automatically labels head and neck of the femur and greater trochanter.

\section{C- For measuring distal forearm BMD:}

- The patient sits on a chair and put the forearm on the scan table in pronated position. The scan arm and detector move to the approximate start position and the program turns on the laser light.

- Put the laser light midway the wrist joint. 
Effect of Selective Serotonin Reuptake Inhibitors and Serotonin....

- The program automatically labels the distal forearm.

\section{A definition of common terms shown on the report:}

- BMD (Bone Mineral Density): The $\mathrm{BMD}$ value gives a Measurement of bone mineral found in the region of interest. BMD is measured in grams per centimeter squared $\left(\mathrm{g} / \mathrm{cm}^{2}\right)$.

- Area: This value identifies the area of the scan region measured in $\mathrm{cm} 2$.
- T- Score (\% young adult).: This value compares a patient's BMD with the expected peak bone mass for a subject of approximately 20-40 years old.

- Z- Score (\% Age- Matched): This value compares a patient's BMD with the expected values of the reference group of the same age and gender. 
Hesham Hamoud et al.
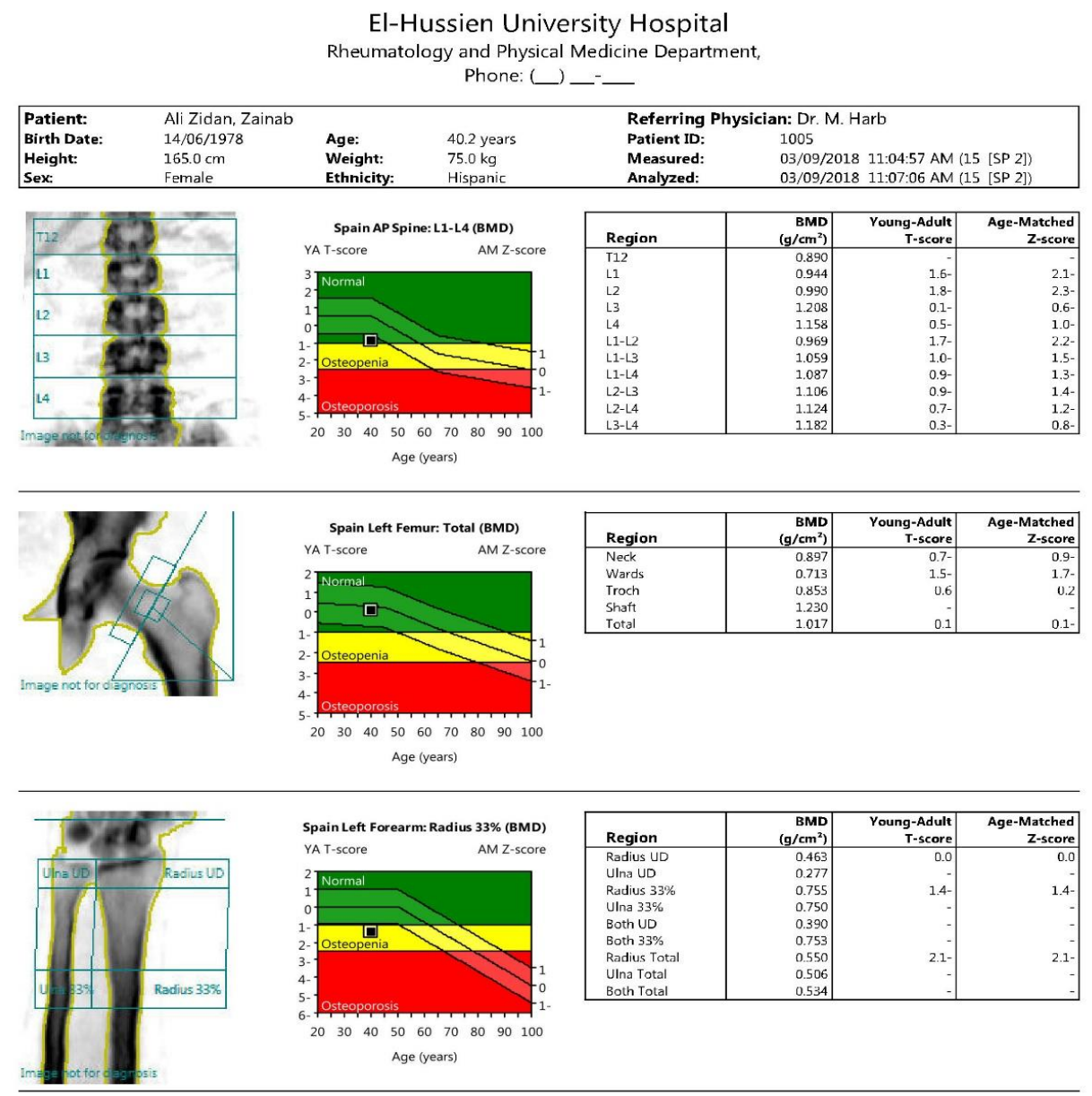

\begin{tabular}{|l|r|r|r|}
\hline Region & BMD & Young-Adult & Age-Matched \\
$\mathbf{( g / \mathbf { c m } ^ { \mathbf { 2 } } )}$ & T-score & $\begin{array}{r}\text { Z-score } \\
\hline \text { Radius UD }\end{array}$ \\
Ulna UD & 0.463 & 0.0 & 0.0 \\
Radius 33\% & 0.277 & - & - \\
Ulna3 33\% & 0.755 & 1.4 & $1.4-$ \\
Both UD & 0.750 & - & - \\
Both 33\% & 0.390 & - & - \\
Radius Total & 0.753 & - & - \\
Ulna Total & 0.550 & $2.1-$ & $2.1-$ \\
Both Total & 0.506 & - & - \\
\hline
\end{tabular}

Statistically 68\%, of repeat scalis fall within 1 SD $\left( \pm 0.010 \mathrm{~g} / \mathrm{cm}^{2}\right.$ for AP Soine LI-L4); $\left( \pm 0.012 \mathrm{~g} / \mathrm{cm}^{2}\right.$ for Left Femur Total); $\left\{0.020 \mathrm{~g} / \mathrm{cm}^{2}\right.$ for Left Forearm Racius 33\%); Spain (ages 20-40) AP Spinte

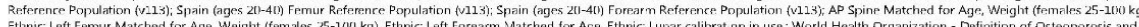

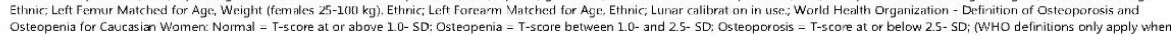
young healthy Caucasian women reference database is used to determine 1-scores)

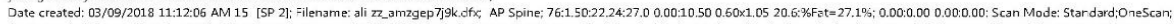

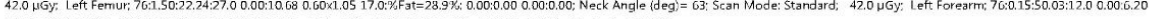

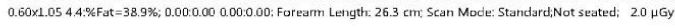

(88) GE Healthcare

Figure 1: DXA report

\section{F-Trabecular Bone Score (TBS) of lumber spine}

Assessment of Trabecular Bone Score (TBS) of lumber spine using TBS iNsight § software (Version 2.0), distributed by Med-Imaps and installed on (GE Lunar: Prodigy), High TBS value means that the bone microarchitecture is dense and well-connected, with little space between spans. Conversely, a low TBS value means that the bone microarchitecture is incomplete, with large spaces between spans. In clinical practice, TBS is calculated in a few seconds, using images obtained during BMD examination along with the software TBS iNsight ${ }^{\circledR}$, which is installed 
Effect of Selective Serotonin Reuptake Inhibitors and Serotonin....

directly onto bone densitometer. Trabeculometry is the measurement of TBS, and trabeculography is the color map of local TBS values on the L1-L4 vertebrae,

TBS $\geq 1.350$ is normal while as partially degraded when $1.200<$ TBS $<1.350$ and degraded when TBS $\leq 1.200$.

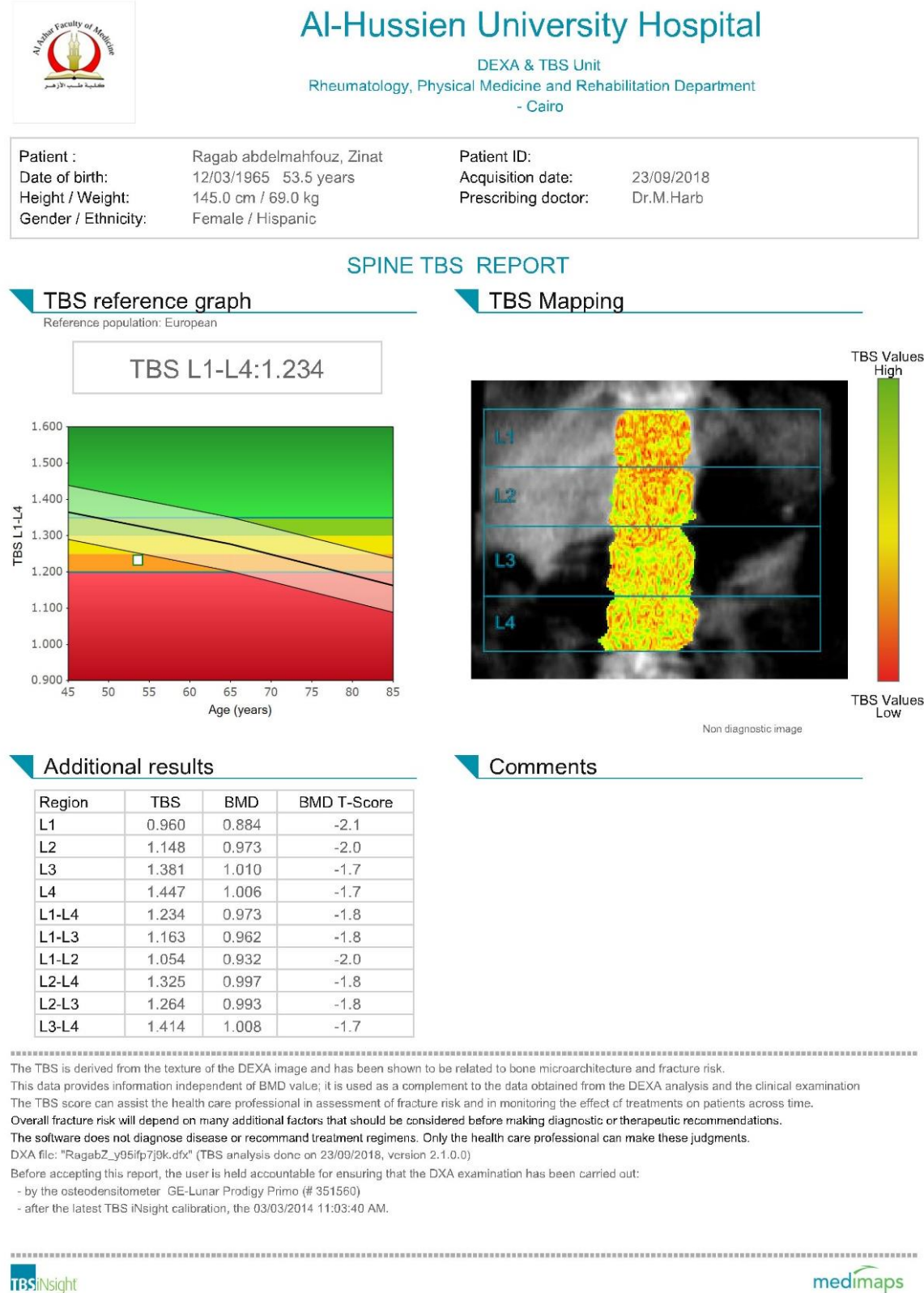

Figure 2: TBS report

Statistical analysis: Recorded data were analyzed using the statistical package for social sciences, version 20.0 (SPSS Inc., Chicago, Illinois, USA). Quantitative data were expressed as mean \pm standard deviation (SD). Qualitative data were expressed as frequency and percentage.
The following tests were done: A one-way analysis of variance (ANOVA) when comparing between more than two means. Post Hoc test: Least Significant Difference (LSD) was used for multiple comparisons between different variables. Independent-samples t-test of significance 
Hesham Hamoud et al.

was used when comparing between two means. Chi-square (x2) test of significance was used in order to compare proportions between qualitative parameters. Pearson's correlation coefficient (r) test was used to assess the degree of association between two sets of variables. The confidence interval

\section{.RESULTS}

was set to $95 \%$ and the margin of error accepted was set to $5 \%$. So, the p-value was considered significant as the following: Probability (P-value): P-value $<0.05$ was considered significant. P-value $<0.001$ was considered as highly significant. P-value $>0.05$ was considered insignificant

Table 1: comparison between groups according to the demographic data

\begin{tabular}{|c|c|c|c|c|c|c|}
\hline Data & SSRI $(n=50)$ & SNRI $(n=50)$ & $\begin{array}{c}\text { Control FMS } \\
(n=25)\end{array}$ & $\begin{array}{c}\text { Healthy control } \\
(n=25)\end{array}$ & $F / x 2 \#$ & p-value \\
\hline Age (years) & & & & & \multirow{5}{*}{0.054} & \multirow{5}{*}{0.983} \\
\hline Mean \pm SD & $45.08 \pm 9.49$ & $45.50 \pm 4.49$ & $44.76 \pm 9.11$ & $45.12 \pm 8.47$ & & \\
\hline Range & 30_60 & 37_55 & 30_60 & 31_60 & & \\
\hline$<45$ years & $24(48.0 \%)$ & $25(50.0 \%)$ & $12(48.0 \%)$ & $12(48.0 \%)$ & & \\
\hline$\geq 45$ years & $26(52.0 \%)$ & $25(50.0 \%)$ & $13(52.0 \%)$ & $13(52.0 \%)$ & & \\
\hline \multicolumn{7}{|l|}{ Height (cm) } \\
\hline Mean \pm SD & $154.78 \pm 8.16$ & $154.71 \pm 10.63$ & $156.99 \pm 6.24$ & $158.44 \pm 9.85$ & \multirow{2}{*}{1.294} & \multirow{2}{*}{0.279} \\
\hline Range & 140_190.5 & 140_190.5 & 145_170 & 122_176 & & \\
\hline \multicolumn{7}{|l|}{ Weight (kg) } \\
\hline Mean \pm SD & $77.86 \pm 20.89$ & $79.09 \pm 23.70$ & $78.54 \pm 17.54$ & $81.46 \pm 14.53$ & \multirow{2}{*}{0.176} & \multirow{2}{*}{0.913} \\
\hline Range & 27.2_115 & $27.2 \_115$ & 27.2_100 & 40.8_112 & & \\
\hline \multicolumn{7}{|l|}{ BMI $\left[w t /(h t)^{\wedge} 2\right]$} \\
\hline Mean \pm SD & $33.03 \pm 8.59$ & $33.28 \pm 10.14$ & $31.82 \pm 6.77$ & $32.72 \pm 6.66$ & \multirow{2}{*}{0.170} & \multirow{2}{*}{0.917} \\
\hline Range & $11.7 \_46.2$ & 11.71_46.22 & $11.7 \_40.8$ & $15.4 \_46.4$ & & \\
\hline \multicolumn{7}{|l|}{ Obesity } \\
\hline Normal & $9(18.0 \%)$ & $11(22.0 \%)$ & $2(8.0 \%)$ & $2(8.0 \%)$ & \multirow{3}{*}{$4.200 \#$} & \multirow{3}{*}{0.072} \\
\hline Overweight & $4(8.0 \%)$ & $3(6.0 \%)$ & $8(32.0 \%)$ & $5(20.0 \%)$ & & \\
\hline Obese & $37(74.0 \%)$ & $36(72.0 \%)$ & $15(60.0 \%)$ & $18(72.0 \%)$ & & \\
\hline
\end{tabular}

According to the demographic data; all subjects were Egyptian with age ranged from 30 to 60 years old.

As regard the comparison between the groups according to demographic data, there was no statistically significant difference between them.

I- Comparison between groups according to L1-L4 BMD and BMC.

Table 2: comparison between the groups according to AP lumber spine L1-L4 BMD and $\mathrm{BMC}$

\begin{tabular}{|c|c|c|c|c|c|c|}
\hline & SSRI $(n=50)$ & SNRI $(n=50)$ & $\begin{array}{l}\text { Control FMS } \\
(n=25)\end{array}$ & $\begin{array}{l}\text { Healthy control } \\
(n=25)\end{array}$ & ANOVA & p-value \\
\hline AP Spine L1-L4 BMD & & & & & & \\
\hline Mean \pm SD & $0.99 \pm 0.13$ & $1.10 \pm 0.15 \mathrm{a}$ & $1.06 \pm 0.15 \mathrm{a}$ & $1.21 \pm 0.09 \mathrm{abc}$ & 15 & ( \\
\hline Range & $0.74 \_1.38$ & $0.61 \_1.44$ & $0.74 \_1.29$ & $1.09 \_1.40$ & $15.4 / 1$ & -0.001 \\
\hline AP Spine L1-L4 BMC & & & & & & \\
\hline
\end{tabular}


Effect of Selective Serotonin Reuptake Inhibitors and Serotonin....

\begin{tabular}{l|l|l|l|l|l|} 
Mean \pm SD & $48.63 \pm 9.15$ & $57.94 \pm 9.67 \mathrm{a}$ & $52.66 \pm 10.31$ & $60.36 \pm 9.22 \mathrm{ac}$ & 11.920 \\
Range & $35.00 \_72.15$ & $33.64 \_80.00$ & $33.76 \_71.48$ & $46.85 \_79.13$ & $<0.001 * *$ \\
\hline
\end{tabular}

As regard the comparison between the groups according to AP lumber spine L1-L4 BMD and

BMC. There was highly statistically significant difference

Table 3: comparison between the groups according to L1-L4 T-score and z-score

\begin{tabular}{|c|c|c|c|c|c|c|}
\hline L1-L4 & $\operatorname{SSRI}(n=50)$ & SNRI $(n=50)$ & $\begin{array}{c}\text { Control FMS } \\
(n=25)\end{array}$ & $\begin{array}{l}\text { Healthy control } \\
\qquad(n=25)\end{array}$ & F/x2\# & p-value \\
\hline $\begin{array}{l}\text { L1-L4 T-Score } \\
\text { Mean } \pm \text { SD } \\
\text { Range } \\
\end{array}$ & $\begin{array}{l}-1.94 \pm 1.04 \\
-3.70 \_1.51 \\
\end{array}$ & $\begin{array}{l}-2.31 \pm 0.83 a \\
-4.68 \_-1.12 \\
\end{array}$ & $\begin{array}{c}-1.08 \pm 1.21 \mathrm{ab} \\
-3.65 \_0.77\end{array}$ & $\begin{array}{c}0.09 \pm 0.73 a b c \\
-0.84 \_1.64\end{array}$ & 39.542 & $<0.001 * *$ \\
\hline $\begin{array}{l}\text { Normal } \\
\text { Osteopenia } \\
\text { Osteoporosis }\end{array}$ & $\begin{array}{c}9(18.0 \%) \\
20(40.0 \%) \\
21(42.0 \%) \\
\end{array}$ & $\begin{array}{c}0(0.0 \%) \\
29(58.0 \%) \\
21(42.0 \%)\end{array}$ & $\begin{array}{c}14(56.0 \%) \\
6(24.0 \%) \\
5(20.0 \%)\end{array}$ & $\begin{array}{c}25(100.0 \%) \\
0(0.0 \%) \\
0(0.0 \%)\end{array}$ & 88.795\# & $<0.001 * *$ \\
\hline $\begin{array}{l}\text { L1-L4 Z-Score } \\
\text { Mean } \pm \text { SD } \\
\text { Range }\end{array}$ & $\begin{array}{l}-1.35 \pm 1.07 \\
-3.36 \_2.55\end{array}$ & $\begin{array}{c}-0.75 \pm 1.35 \mathrm{a} \\
-4.34 \_2.79\end{array}$ & $\begin{array}{c}-0.86 \pm 1.28 \mathrm{a} \\
-2.66 \_1.53\end{array}$ & $\begin{array}{c}-0.02 \pm 1.03 \mathrm{abc} \\
-1.71 \_2.55\end{array}$ & 6.974 & $<0.001 * *$ \\
\hline $\begin{array}{l}\text { Normal } \\
\text { Osteopenia } \\
\text { Osteoporosis }\end{array}$ & $\begin{array}{c}17(34.0 \%) \\
26(52.0 \%) \\
7(14.0 \%)\end{array}$ & $\begin{array}{c}30(60.0 \%) \\
15(30.0 \%) \\
5(10.0 \%)\end{array}$ & $\begin{array}{c}13(52.0 \%) \\
10(40.0 \%) \\
2(8.0 \%)\end{array}$ & $\begin{array}{c}21(84.0 \%) \\
4(16.0 \%) \\
0(0.0 \%)\end{array}$ & 18.594\# & $0.005^{*}$ \\
\hline
\end{tabular}

As regard the comparison between the groups according to L1-L4 T-score and z-score. There was highly statistically significant difference between groups according to L1-L4 T-score and Z-score.

Table 4: comparison between the groups according to TBS L1-L4

\begin{tabular}{|c|c|c|c|c|c|c|}
\hline TBS L1-L4 & $\begin{array}{c}\text { SSRI } \\
(n=50)\end{array}$ & $\begin{array}{c}\text { SNRI } \\
(n=50)\end{array}$ & $\begin{array}{c}\text { Control FMS } \\
\qquad(n=25)\end{array}$ & $\begin{array}{l}\text { Healthy } \\
\text { control } \\
(n=25) \\
\end{array}$ & F/x2\# & p-value \\
\hline $\begin{array}{l}\text { TBS L1-L4 } \\
\text { Mean } \pm \text { SD } \\
\text { Range }\end{array}$ & $\begin{array}{l}1.32 \pm 0.16 \\
0.94 \_1.71\end{array}$ & $\begin{array}{l}1.28 \pm 0.23 \\
0.27 \_1.61\end{array}$ & $\begin{array}{c}1.46 \pm 0.19 \mathrm{ab} \\
0.99 \_1.75\end{array}$ & $\begin{array}{c}1.44 \pm 0.17 \mathrm{ab} \\
0.79 \_1.63\end{array}$ & 7.361 & $<0.001 * *$ \\
\hline $\begin{array}{l}\text { TBS L1-L4 } \\
\text { Degraded } \\
\text { Partially degraded } \\
\text { Normal } \\
\end{array}$ & $\begin{array}{c}12(24.0 \%) \\
8(16.0 \%) \\
30(60.0 \%) \\
\end{array}$ & $\begin{array}{l}11(22.0 \%) \\
11(22.0 \%) \\
28(56.0 \%) \\
\end{array}$ & $\begin{array}{c}2(8.0 \%) \\
3(12.0 \%) \\
20(80.0 \%)\end{array}$ & $\begin{array}{c}1(4.0 \%) \\
1(4.0 \%) \\
23(92.0 \%) \\
\end{array}$ & $13.678 \#$ & $0.033^{*}$ \\
\hline
\end{tabular}

As regard the comparison between groups according to TBS L1-L4, there was a highly statistically significant difference between groups according to TBS L1-L4.

Table 5: comparison between the groups according to left femur total BMD and BMC

\begin{tabular}{|c|c|c|c|c|c|c|}
\hline & SSRI $(n=50)$ & $\begin{array}{c}\text { SNRI } \\
(n=50)\end{array}$ & $\begin{array}{c}\text { Control } \\
\text { FMS }(n=25)\end{array}$ & $\begin{array}{c}\text { Healthy } \\
\text { control }(n=25)\end{array}$ & ANOVA & p-value \\
\hline $\begin{array}{l}\text { Left Femur Total BMD } \\
\text { Mean } \pm \text { SD } \\
\text { Range }\end{array}$ & $\begin{array}{l}0.89 \pm 0.18 \\
0.49 \_1.78\end{array}$ & $\begin{array}{c}0.99 \pm 0.17 \mathrm{a} \\
0.74 \_1.78\end{array}$ & $\begin{array}{c}0.97 \pm 0.11 \mathrm{a} \\
0.75 \_1.14\end{array}$ & $\begin{array}{c}1.04 \pm 0.12 \mathrm{abc} \\
0.78 \_1.28\end{array}$ & 6.001 & $<0.001 * *$ \\
\hline $\begin{array}{l}\text { Left Femur Total BMC } \\
\text { Mean } \pm \text { SD } \\
\text { Range }\end{array}$ & $\begin{array}{c}27.02 \pm 4.44 \\
14.67 \quad 34.46\end{array}$ & $\begin{array}{l}30.20 \pm 5.48 \mathrm{a} \\
19.75 \quad 45.70\end{array}$ & $\begin{array}{l}30.40 \pm 4.69 a \\
20.47 \quad 37.23\end{array}$ & $\begin{array}{c}32.63 \pm 4.49 \mathrm{abc} \\
23.43 \quad 42.07\end{array}$ & 8.437 & $<0.001 * *$ \\
\hline
\end{tabular}


Hesham Hamoud et al.

As regard the comparison between the groups according to left femur total BMD and BMC there was highly statistically significant difference between groups according to left femur total BMD and BMC.

As regard the comparison between groups according to left femur total T-score and zscore, there was highly statistically significant difference between groups according to left femur total T-score and Z-score

Table 6: comparison between groups according to left femur total T-score and z-score

\begin{tabular}{|c|c|c|c|c|c|c|}
\hline & $\begin{array}{l}\text { SSRI } \\
(n=50)\end{array}$ & $\begin{array}{l}\text { SNRI } \\
(n=50)\end{array}$ & $\begin{array}{l}\text { Control FMS } \\
(n=25)\end{array}$ & $\begin{array}{l}\text { Healthy } \\
\text { control } \\
(n=25)\end{array}$ & F/x2\# & p-value \\
\hline $\begin{array}{l}\text { Left Femur Total T-Score } \\
\text { Mean } \pm \text { SD } \\
\text { Range }\end{array}$ & $\begin{array}{l}-0.90 \pm 1.47 \\
-4.28 \_6.48\end{array}$ & $\begin{array}{l}-0.07 \pm 1.43 a \\
-2.14 \_6.48\end{array}$ & $\begin{array}{l}-0.23 \pm 0.93 a b \\
-2.05 \_1.12\end{array}$ & $\begin{array}{l}0.32 \pm 0.96 a b c \\
-1.84 \_2.34\end{array}$ & 5.907 & $<0.001 * *$ \\
\hline $\begin{array}{l}\text { Left Femur Total T-Score } \\
\text { Normal } \\
\text { Osteopenia } \\
\text { Osteoporosis }\end{array}$ & $\begin{array}{l}23(46.0 \%) \\
25(50.0 \%) \\
2(4.0 \%)\end{array}$ & $\begin{array}{l}37(74.0 \%) \\
13(26.0 \%) \\
0(0.0 \%)\end{array}$ & $\begin{array}{l}20(80.0 \%) \\
5(20.0 \%) \\
0(0.0 \%) \\
\end{array}$ & $\begin{array}{l}23(92.0 \%) \\
2(8.0 \%) \\
0(0.0 \%)\end{array}$ & 22.198\# & $<0.001 * *$ \\
\hline $\begin{array}{l}\text { Left Femur Total Z-Score } \\
\text { Mean } \pm \text { SD } \\
\text { Range }\end{array}$ & $\begin{array}{l}-0.88 \pm 1.39 \\
-3.03 \_6.43\end{array}$ & $\begin{array}{l}-0.39 \pm 1.41 \mathrm{a} \\
-2.77 \_6.43\end{array}$ & $\begin{array}{l}-0.25 \pm 0.91 \mathrm{ab} \\
-1.81 \_1.81\end{array}$ & $\begin{array}{l}0.10 \pm 0.91 \mathrm{abc} \\
-1.65 \_2.07\end{array}$ & 3.758 & $0.012 *$ \\
\hline $\begin{array}{l}\text { Left Femur Total Z-Score } \\
\text { Normal } \\
\text { Osteopenia } \\
\text { Osteoporosis }\end{array}$ & $\begin{array}{l}25(50.0 \%) \\
24(48.0 \%) \\
1(2.0 \%)\end{array}$ & $\begin{array}{l}35(70.0 \%) \\
14(28.0 \%) \\
1(2.0 \%)\end{array}$ & $\begin{array}{l}19(76.0 \%) \\
6(24.0 \%) \\
0(0.0 \%)\end{array}$ & $\begin{array}{l}24(96.0 \%) \\
1(4.0 \%) \\
0(0.0 \%)\end{array}$ & 17.866\# & $0.007 *$ \\
\hline
\end{tabular}

Table 7: comparison between groups according to left forearm total T-score and Z-score

\begin{tabular}{|c|c|c|c|c|c|c|}
\hline & $\begin{array}{c}\text { SSRI } \\
(n=50)\end{array}$ & $\begin{array}{c}\text { SNRI } \\
(n=50)\end{array}$ & $\begin{array}{l}\text { Control FMS } \\
\qquad(n=25)\end{array}$ & $\begin{array}{c}\text { Healthy } \\
\text { control }(n=25)\end{array}$ & F/x2\# & p-value \\
\hline $\begin{array}{l}\text { Left Forearm Total T-Score } \\
\text { Mean } \pm \text { SD } \\
\text { Range }\end{array}$ & $\begin{array}{l}-1.97 \pm 1.49 \\
-5.57 \_2.01\end{array}$ & $\begin{array}{c}-0.89 \pm 1.64 \mathrm{a} \\
-5.57 \_3.12\end{array}$ & $\begin{array}{c}-0.95 \pm 1.82 \mathrm{ab} \\
-5.19 \_2.37 \\
\end{array}$ & $\begin{array}{c}-0.29 \pm 1.18 \mathrm{abc} \\
-2.05 \_1.79\end{array}$ & 7.820 & $<0.001 * *$ \\
\hline $\begin{array}{l}\text { Left Forearm Total T-Score } \\
\text { Normal } \\
\text { Osteopenia } \\
\text { Osteoporosis } \\
\end{array}$ & $\begin{array}{l}15(30.0 \%) \\
17(34.0 \%) \\
18(36.0 \%)\end{array}$ & $\begin{array}{l}27(54.0 \%) \\
15(30.0 \%) \\
8(16.0 \%)\end{array}$ & $\begin{array}{l}12(48.0 \%) \\
9(36.0 \%) \\
4(16.0 \%)\end{array}$ & $\begin{array}{c}15(60.0 \%) \\
10(40.0 \%) \\
0(0.0 \%)\end{array}$ & 17.095 & $0.009^{*}$ \\
\hline $\begin{array}{l}\text { Left Forearm Total Z-Score } \\
\text { Mean } \pm \text { SD } \\
\text { Range }\end{array}$ & $\begin{array}{l}-1.65 \pm 1.47 \\
-5.57 \_2.01\end{array}$ & $\begin{array}{c}-0.81 \pm 1.63 \mathrm{a} \\
-5.57 \_3.12\end{array}$ & $\begin{array}{c}-0.69 \pm 1.78 \mathrm{ab} \\
-5.19 \_2.37\end{array}$ & $\begin{array}{c}-0.13 \pm 1.14 \mathrm{abc} \\
-2.05 \_2.49\end{array}$ & 6.175 & $<0.001 * *$ \\
\hline $\begin{array}{l}\text { Left Forearm Total Z-Score } \\
\text { Normal } \\
\text { Osteopenia } \\
\text { Osteoporosis }\end{array}$ & $\begin{array}{l}17(34.0 \%) \\
19(38.0 \%) \\
14(28.0 \%)\end{array}$ & $\begin{array}{l}28(56.0 \%) \\
14(28.0 \%) \\
8(16.0 \%)\end{array}$ & $\begin{array}{l}14(56.0 \%) \\
7(28.0 \%) \\
4(16.0 \%)\end{array}$ & $\begin{array}{c}19(76.0 \%) \\
6(24.0 \%) \\
0(0.0 \%)\end{array}$ & 15.221 & $0.019^{*}$ \\
\hline
\end{tabular}

As regard the comparison between groups according to left forearm total T-score and Zscore, there was highly statistically significant difference between groups according to left forearm total T-score and left forearm total Z-score.

Table 8: comparison between age $<45$ years versus $\geq 45$ years according to $T$-score and Z-score in SSRI group

\begin{tabular}{|l|c|c|c|c|c|c|}
\hline \multirow{2}{*}{ SSRI } & \multicolumn{2}{|c|}{$<45$ years } & \multicolumn{2}{|c|}{$\geq 45$ years } & \multicolumn{2}{c|}{ t-test } \\
\cline { 2 - 7 } & Mean & \pm SD & Mean & \pm SD & t & p-value \\
\hline
\end{tabular}


Effect of Selective Serotonin Reuptake Inhibitors and Serotonin....

\begin{tabular}{|l|c|c|c|c|c|c|} 
L1-L4 T-Score & -1.58 & 1.08 & -2.26 & 0.89 & 5.982 & $0.018^{*}$ \\
\hline L1-L4 Z-Score & -1.25 & 1.16 & -1.45 & 1.00 & 0.413 & 0.524 \\
\hline Left Femur Total T-Score & -0.54 & 1.74 & -1.23 & 1.10 & 2.843 & 0.098 \\
\hline Left Femur Total Z-Score & -0.62 & 1.74 & -1.12 & 0.94 & 1.636 & 0.207 \\
\hline Left Forearm Total T-Score & -1.47 & 1.58 & -2.43 & 1.27 & 5.671 & $0.021^{*}$ \\
\hline Left Forearm Total Z-Score & -1.25 & 1.60 & -2.01 & 1.26 & 3.530 & $0.046^{*}$ \\
\hline
\end{tabular}

This table showed statistically significant difference between age <45 years and $\geq 45$ years according to L1-L4 T-score, Left Forearm Total T-Score and Left Forearm Total Z-Score.

\section{DISCUSSION}

According to White and Harth ${ }^{(10)}$

Fibromyalgia was second only to osteoarthritis among new consults and it was the only disorder perceived by a majority $(69.3 \%)$ with increased in frequency within the practices over the previous 5 years. FM now also appears to account for a significant percentage of patients seen in family practice clinics $2.1 \%$, general medicine clinics $5.7 \%$ and hospitals $7.5 \%$. Carville $\boldsymbol{e t}$ al. ${ }^{(10)}$ (SNRIs) duloxetine and milnacipran had been approved by the US Food and Drug Administration for the management of fibromyalgia and appear to be more effective in relieving fibromyalgia symptoms than are the SSRIs. Atzeni ${ }^{(12)}$ reported that (SSRIs) such as citalopram, fluoxetine, escitalopram, fluvoxamine, paroxetine, and sertraline may be helpful in treating depression and/or anxiety symptoms, they are superior to placebo in treating the key FM symptoms of pain, fatigue, or sleep dysfunction.

Cosman $^{(13)}$ reported that BMD testing was a vital component in the diagnosis and management of osteoporosis. BMD has been shown to correlate with bone strength and is an excellent predictor of future fracture risk. DXA measurements must be performed by appropriately trained technologists on properly maintained instruments. DXA scans are associated with the risk of exposure to radiation mostly trivial amounts.

According to Mateos $^{(14)}$ the association between fibromyalgia and osteoporosis was theoretically sound, since some risk factors were common for both fibromyalgia and osteoporosis. Gender is an example, as the two diseases are more frequent in women. In a study of Moura and his colleagues (15) they found that selective serotonin reuptake inhibitors (SSRIs) and serotonin and noradrenaline reuptake inhibitors (SNRIs) usage may increase the risk of falls, decrease bone mineral density (BMD), and result in subsequent fractures even after controlling for multiple risk factors. The present study provided evidence that usage of SSRIs or SNRI is significantly associated with low BMD (osteopenia \& osteoporosis) specially spine BMD reduction with low TBS (Partially degraded and degraded) particularly for old people, and despite low BMD was found in the SRI users; it also found in $1^{\text {ry }}$ fibromyalgia not on SRIs so $1^{\text {ry }}$ fibromyalgia should also be considered as a contributing factor for low BMD. These results are in accordance with those of Zhou $^{(4)}$ who concluded that SSRIs and SNRIs have a reducing effect on BMD, and in accordance with $\mathbf{U p a l a}^{(2)}$ concluded that FMS is associated with decreased BMD at the lumbar spine (L2-L4) compared with normal individuals. Hence, we recommend eliminating other risk factors to avoid osteoporosis and take calcium and vitamin D in daily recommended doses for preventing osteoporosis, also switch old patients on SSRIs user for fibromyalgia to another regimen.

\section{CONCLUSION}

The present study provided evidence that usage of SSRIs or SNRI was significantly associated with low BMD (Osteopenia and osteoporosis) specially spine BMD reduction with low TBS (Partially degraded and degraded) particularly for old people and despite low BMD was found in the SRI users; it also found in $1^{\text {ry }}$ fibromyalgia not on SRIs so $1^{\text {ry }}$ 
Hesham Hamoud et al.

fibromyalgia should also be considered as a contributing factor for low BMD.

\section{REFERENCES}

1. Jay $G$ and Barkin $R$ (2015): Fibromyalgia. Disease Month., 61(3): 66-111.

2. Upala $S$ Yong $W$ and Sanguankeo A (2017): Bone mineral density is decreased in fibromyalgia syndrome: a systematic review and metaanalysis. Rheumatology International, 37(4): 617-622.

3. Nutt D J, Forshall S, Bell C, Rich $A$, Sandford $J$, Nash $J$ and Argyropoulos S (1999): Mechanisms of action of selective serotonin reuptake inhibitors in the treatment of psychiatric disorders. European

Neuropsychopharmacology, 9:8186.

4. Zhou C et al. (2018): Effect of selective serotonin reuptake inhibitors on bone mineral density: a systematic review and metaanalysis. Osteoporosis International, 29: 1-9.

5. Ablin J and Buskila D (2013): Fibromyalgia syndrome-Novel therapeutic targets. Maturitas, 75(4):335-340.

6. Moura $\mathrm{C}$ et al. (2014): Antidepressant use and 10-year incident fracture risk: the population-based Canadian multicentre osteoporosis study (CaMoS). Osteoporosis International, 25(5):1473-1481.

7. Bousson, $\mathrm{V}$ et al. (2012): Knowledge, clinical relevance, and future prospects. Osteoporos Int., 23(5): 1489-1501.

8. Hans D et al. (2011): Correlations between trabecular bone score, measured using anteroposterior dual-energy X-ray absorptiometry acquisition, and 3-dimensional parameters of bone microarchitecture: an experimental study on human cadaver vertebrae. Journal of Clinical Densitometry, 14(3): 302-312.

9. Shevroja E, Lamy O, Kohlmeier L, Koromani F, Rivadeneira F and Hans D (2017): Use of trabecular bone score (TBS) as a complementary approach to dualenergy X-ray absorptiometry (DXA) for fracture risk assessment in clinical practice. Journal of Clinical Densitometry, 20(3): 334-345.

10. White $K$ and Harth $M$ (2001): Classification, epidemiology, and natural history of fibromyalgia. Current Pain and Headache Reports,5(4): 320-329.

11. Carville S et al. (2008). EULAR evidence-based recommendations for the management of fibromyalgia syndrome. Annals of the Rheumatic Diseases, 67(4): 536-541.

12. Atzeni, F et al. (2017): An update on emerging drugs for fibromyalgia treatment. Expert opinion on emerging drugs, 22(4):357-367.

13. Cosman F et al. (2014): Clinician's guide to prevention and treatment of osteoporosis. Osteoporosis International, 25(10):2359-2381.

14. Mateos F et al. (2014): Bone mass and vitamin D levels in women with a diagnosis of fibromyalgia. Osteoporosis International, 25(2):525-533.

15. Moura C, Bernatsky $S$ et al. (2014). Antidepressant use and 10year incident fracture risk: the population-based Canadian Multicentre Osteoporosis Study (CaMoS).Osteoporosis International, 25(5): 1473-1481. 